\title{
Epidemiology and public health journals on the internet
}

\author{
Esteve Fernández, Jordi Sobrequés, Anna Schiaffino
}

The internet offers public health students and professionals direct access to the main journals in the field via the world wide web. ${ }^{1-3}$ Most epidemiology and public health journals have constructed sites on the world wide web that reproduce their paper editions. These web sites offer varied information of varied value for users: from lists of contents (of current and past issues) to free access to full text articles. Thus, public health professionals and students, as well as the public, can access this valuable information even before the issue of the journal arrives in the library or onto our desks. What we find varies according to the publishers' wishes and/or possibilities. However, no comprehensive review of the contents of the web sites of journals devoted to epidemiology and public health has been carried out.

The purpose of this brief review was to describe the contents and services of the web sites of the main journals in the field of epidemiology and public health available on the internet to date (October 1998).

\section{Methods}

JOURNALS AND WEB SITES SELECTED

General epidemiology and public health journals with web sites were first identified through available resource catalogues on the internet. ${ }^{4-7}$ Journals in English and with a general and international scope were chosen. We hope to have included most of the journals available in regular university and health department libraries that are typically consulted by public health professionals. Journals on specific fields within epidemiology and public health (for example, surveillance, cancer, cardiovascular, health promotion, health care services, etc) have been intentionally omitted. Table 1 lists the 14 journals finally selected together with their web site addresses (known as URL or universal resource locator, in internet terminology).

\section{METHODOLOGY AND ITEMS REVIEWED}

We systematically reviewed the journals' web pages using a structured questionnaire, which was designed after browsing the web pages of the British Medical fournal, the Lancet, and the New England fournal of Medicine. The questionnaire included the following sections and items: journal information (editorial policy statement, instructions for authors, editorial board, subscribers' information, reprints services' details); current issue contents (index, titles, authors, pages, abstract, full article text, type of articles available); past issues contents (index, titles, authors, pages, abstract, full article text, type of articles available, and first issue available); presence of search tools; other services available (related links, contents by email, impact factor, academic and professional advertisements, commercial advertisements, etc).

In the first instance, the authors independently accessed the journals' web pages and
Institut Universitari de Salut Pública de Catalunya, L'Hospitalet, Barcelona, Spain

Correspondence to: Dr E Fernández, Institut Universitari de Salut Pública de Catalunya, Campus de Bellvitge, Universitat de Barcelona, Ctra Feixa Llarga s/n, 08907 L'Hospitalet, Barcelona, Spain.

Accepted for publication 29 January 1999
Table 1 Names, Medline abbreviation, and web site addresses (URL, universal resource locator) of the 14 journals selected.

\begin{tabular}{|c|c|c|}
\hline fournal & Medline abbreviation & $U R L$ \\
\hline American fournal of Epidemiology & Am J Epidemiol & http://www.jhsph.edu/pubs/jepi \\
\hline American fournal of Preventive Medicine & Am J Prev Med & http://www-east.elsevier.com/ajpm \\
\hline American fournal of Public Health & Am J Public Health & $\begin{array}{l}\text { http://www.apha.org/news/publications/ } \\
\text { publications.html }\end{array}$ \\
\hline Annals of Epidemiology & Ann Epidemiol & http://www.elsevier.nl/locate/annepidem \\
\hline Annual Review of Public Health & Annu Rev Public Health & http://www.AnnualReviews.org/ari \\
\hline Epidemiologic Reviews & Epidemiologic Rev & http://www.jhsph.edu/pubs/jepi \\
\hline Epidemiology & Epidemiology & $\begin{array}{l}\text { http://www.wwilkins.com/EDE/ } \\
\text { index.html }\end{array}$ \\
\hline European fournal of Epidemiology & Eur J Epidemiol & $\begin{array}{l}\text { http://www.wkap.nl/journalhome.htm/ } \\
\text { 0393-2990 }\end{array}$ \\
\hline European Fournal of Public Health & Eur J Public Health & http://www.oup.co.uk/jnls/list/eurpub/ \\
\hline International fournal of Epidemiology & Int J Epidemiol & http://www.oup.co.uk/jnls/list/ije/ \\
\hline fournal of Clinical Epidemiology & J Clin Epidemiol & http:// www.elsevier.n1/locate/jclinepi \\
\hline fournal of Epidemiology and Community Health & J Epidemiol Community Health & http://www.bmipg.com/data/ech.htm \\
\hline Preventive Medicine & Prev Med & $\begin{array}{l}\text { http://www.apnet.com/www/journal/ } \\
\text { pm.htm }\end{array}$ \\
\hline Public Health & Public Health & $\begin{array}{l}\text { http://www.stockton-press.co.uk/ph/ } \\
\text { index.html }\end{array}$ \\
\hline
\end{tabular}


Table 2 Main characteristics of the web sites reviewed for the selected 14 journals (sites last visited during October, 1998)

\begin{tabular}{|c|c|c|c|c|c|c|c|}
\hline & \multirow[b]{2}{*}{ Current issue } & \multicolumn{3}{|l|}{ Past issues } & \multirow{2}{*}{$\begin{array}{l}\text { Search } \\
\text { tool }\end{array}$} & \multirow{2}{*}{$\begin{array}{l}\text { Reprints } \\
\text { service }\end{array}$} & \multirow{2}{*}{$\begin{array}{l}\text { Email } \\
\text { contents } \\
\text { service }\end{array}$} \\
\hline & & List of contents & Abstracts & Full text & & & \\
\hline Am $\mathcal{F}$ Epidemiol & Contents + abstract & $\begin{array}{l}\text { Jul } 1995 \\
\text { Vol } 142 \text { no } 1\end{array}$ & $\begin{array}{l}\text { Jan } 1996 \\
\text { Vol } 143 \text { no } 1\end{array}$ & No & No & Yes & Yes \\
\hline Am f Prev Med & $\begin{array}{l}\text { Contents }+ \text { abstracts }+ \text { full text selected } \\
\text { papers }\end{array}$ & $\begin{array}{l}\text { Jan/Feb } 1996 \\
\text { Vol } 12 \text { no } 1\end{array}$ & $\begin{array}{l}\mathrm{Jan} / \mathrm{Feb} 1996 \\
\text { Vol } 12 \text { no } 1\end{array}$ & $\begin{array}{l}\text { Selected papers } \\
\text { Jan } 1998 \\
\text { Vol } 14 \text { no } 1\end{array}$ & Yes & No & Yes \\
\hline Am $\mathcal{F}$ Public Health & Contents + selected abstracts & $\begin{array}{l}\text { Jul } 1997 \\
\text { Vol } 87 \text { no } 7\end{array}$ & $\begin{array}{l}\text { Jul } 1997 \\
\text { Vol } 87 \text { no } 7\end{array}$ & No & No & No & No \\
\hline Ann Epidemiol & Contents & $\begin{array}{l}\text { Jan } 1995 \\
\text { Vol } 5 \text { no } 1\end{array}$ & No & No & Yes & No & Yes \\
\hline Annu Rev Public Health & $\begin{array}{l}\text { Contents }+ \text { abstracts }+ \text { full text all } \\
\text { papers }\end{array}$ & $\begin{array}{l}1984 \\
\text { Vol } 5\end{array}$ & $\begin{array}{l}1995 \\
\text { Vol } 16\end{array}$ & No & Yes & Yes & Yes \\
\hline Epidemiologic Review & Contents & $\begin{array}{l}1979 \\
\text { Vol } 1\end{array}$ & No & No & No & No & No \\
\hline Epidemiology & $\begin{array}{l}\text { Contents }+ \text { abstract }+ \text { full text selected } \\
\text { papers }\end{array}$ & $\begin{array}{l}\text { Jan } 1996 \\
\text { Vol } 7 \text { no } 1\end{array}$ & $\begin{array}{l}\text { May } 1996 \\
\text { Vol } 7 \text { no } 3\end{array}$ & $\begin{array}{l}\text { Selected papers } \\
\text { Jan } 1998 \\
\text { Vol } 9 \text { no } 1\end{array}$ & Yes & Yes & No \\
\hline Eur $\mathcal{F}$ Epidemiol & Contents & $\begin{array}{l}\text { Feb } 1995 \\
\text { Vol } 11 \text { no } 1\end{array}$ & No & Sample issue & Yes & No & No \\
\hline Eur $\mathcal{F}$ Public Health & Contents + abstracts & $\begin{array}{l}\text { Mar } 1996 \\
\text { Vol } 6 \text { no } 1\end{array}$ & $\begin{array}{l}\text { Mar } 1996 \\
\text { Vol } 6 \text { no } 1\end{array}$ & No & Yes & No & Yes \\
\hline Int $\mathcal{f}$ Epidemiol & Contents + abstracts & $\begin{array}{l}\text { Feb } 1996 \\
\text { Vol } 25 \text { no } 1\end{array}$ & $\begin{array}{l}\text { Feb } 1996 \\
\text { Vol } 25 \text { no } 1\end{array}$ & Sample issue & Yes & No & Yes \\
\hline f Clin Epidemiol & Contents & $\begin{array}{l}\text { Jan } 1995 \\
\text { Vol } 48 \text { no } 1\end{array}$ & No & No & Yes & No & No \\
\hline $\begin{array}{l}\text { f Epidemiol Community } \\
\text { Health }\end{array}$ & Contents & $\begin{array}{l}\text { Feb } 1996 \\
\text { Vol } 50 \text { no } 1\end{array}$ & No & No & No & Yes & No \\
\hline Prev Med & Contents + abstracts & No & No & Sample issue & No & No & Yes \\
\hline Public Health & Contents + abstracts (free registration) & $\begin{array}{l}\text { Jan } 1997 \\
\text { Vol } 111 \text { no } 1 \\
\text { (free } \\
\text { registration) }\end{array}$ & $\begin{array}{l}\text { Jan } 1997 \\
\text { Vol } 111 \text { no } 1 \\
\text { (free } \\
\text { registration) }\end{array}$ & For subscribers & No & No & Yes \\
\hline
\end{tabular}

completed the questionnaire. Information collected was compared and the authors again jointly accessed all the journal sites to revise and update previous observations and to decide by consensus in the few cases of no agreement. The journals were accessed during October 1998. The data were organised in tables and quantitative and qualitative descriptions of the web sites were derived.

\section{Results}

Once the connection was made, all the web sites accessed were found to be user friendly. After the home page, a series of buttons or a list of links conducted the user to other sections. As these web sites are constructed by publishing groups, links to other journals from the same group were also available, but not to other journals from other publishers. The design of the pages was in general plain, and did not use complicated structures and images, which would make access difficult. As expected, a similar design was observed for journals from the same publishing group (Int F Epidemiol and Eur $\mathcal{F}$ Public Health from Oxford University Press).

"General journal information" such as editorial policy statements, instructions for authors, editors and members of the editorial board, and information for subscribers were present in all the web sites revised. Four of the journals (Am F Public Health, Int $\mathcal{F}$ Epidemiol, $\mathcal{F}$ Epidemiol Community Health, Public Health) mentioned their ISI bibliographic impact factor (figure or rank within the public health, enviroment, and occupation category)

All the web sites provided a table of contents for the current printed issue. The web sites of five journals (Ann Epidemiol, Epidemiologic Review, Eur $\mathcal{F}$ Epidemiol, $\mathcal{F}$ Clin Epidemiol, $\mathcal{F}$ Epi- demiol Community Health) did not offer the corresponding abstracts, while another journal (Am $\mathcal{F}$ Public Health) offered the abstracts of selected articles. Two journals, however, allowed free access to full text of the current issue: Ann Review Public Health to all articles (in PDF format) and Am F Prev Med to selected papers (in HTML and PDF formats).

There was large variability regarding the availability of tables of contents and abstracts for past issues. Except for the two review journals included (Ann Review Public Health and Epidemiologic Review), whose tables of contents began earlier (in 1984 and 1979, respectively), the other journals included contents since 1995 (four journals), 1996 (five journals), and 1997 (two journals). A list of contents was not available for Prev Med. As shown in table 2, abstracts of papers in past issues were available in the same way than those of the current issue. Epidemiology and Am 7 Prev Med allowed free access to the full text of selected papers, while Prev Med and Public Health provided full access for subscribers only. Three journals (Eur f Epidemiol, Int F Epidemiol, Prev Med) allowed users to download full text articles from a sample issue (in PDF format).

Search tools were avaible for eight of the 14 journals revised, permitting searches by keywords and/or authors' names. Information on reprint service was available for four journals, and eight journals offered the possibility of subscribing to an email distribution list of contents for forthcoming issues (named "contents direct" in several web pages) (table 2).

\section{Discussion}

We have systematically reviewed the web pages of the main epidemiology and public health journals on the internet. A quick picture can be 
drawn: besides journal information (instructions for authors, subscriber information, members of editorial boards), contents of current and past issues are to some extent available for all the journals reviewed, but abstracts are not. Access to full text articles is only symbolic.

Although it can be imagined that restricting full text access is based partly on technical, but mainly, on economic and strategic considerations, it is surprising that some journals do not offer at least the abstracts of their papers on the web. In our opinion, the list of contents of current and past issues together with the abstracts of original papers and journal information should be the minimum constituents of a journal web page. Moreover, all abstracts of original papers from journals indexed in Medline (as all the journals reviewed) will be available through the PubMed free service of the US National Library of Medicine on the Internet. ${ }^{8}$ Nowadays, it is possible to directly link to full text articles (for example, the BMF) after locating it via the PubMed. Providing readers with this information in a simple and structured manner could result in increased use and interest among readers, and may even result in higher subscription rates.

A useful, but for the moment rarely implemented service is direct access to contents via email. This service provides up to date information on new papers published, even before reception of the journal in departments, libraries, etc, or even before the journal's web page is updated. This service should be generalised.

For the moment, this first implementation of journals on the internet is far from the foretold death of biomedical journals elsewhere discussed. ${ }^{9}$ Publishing companies have moved to the internet their printed products, and some, but not all, have added new facilities for the retrieval of information. The wish of providing new services to readers and authors is probably the reason for this approach to the internet. Other economic and unknown factors may also operate.

Readers are invited to browse the web sites reviewed to discover for themselves their strengths and limitations, and to note new fea- tures added after the review was done. We hope at least to have prepared the way and made it easier. It should be noted that information and web site addresses are subject to change without previous notification, and what we find today may have changed or may not be there tomorrow. Some colleagues will expect richer web sites, though others may be satisfied. Unfortunately many others, mainly in developing countries, will still have poor or no connection to the world wide web. In developing countries, the internet could play an important part as a means of reducing differences in access to information. For example, free or low cost access to full text in those countries (which would entail simply permitting free or low cost access according to the internet domain ${ }^{10}$ ) would result in greater use and exchange of information between developing and developed countries and would, moreover, help to improve public health and epidemiology debate and research.

Funding: none.

Conflicts of interests: none.

We wish to thank Professor Álvarez-Dardet for suggesting this review.

1 Schwartz DG. Accessing information resources in prevenive medicine: current practice and future trends. Am F Prev Med 1996;12:9-13.

2 López-Abente G, Martín-Moreno JM. Internet and epidemiology. In: Sosa-Iudicissa M, Olivieri M, Gamboa CA, et $a l$, eds. Internet, telematics and health. Amsterdam: IOS Press, 1977:331-7.

3 Fernández E. Internet y salud pública. Gac Sanit 1998;12. 176-181.[URL: http://www.ub.es/isp/intersp.htm].

4 Department of Epidemiology and Biostatistics. San Francisco: University of California. URL: http:// Francisco: University of California. UR
chanane.ucsf.edu/ epidem/epidem.html\#PUB

5 Emory University Health Sciences Center Library. MedEmory University Health Sciences Center Library. Med-
Web. Public Health. URL: http://www.gen.emory.edu/ medweb/medweb.ph.html

6 Institut Universitari de Salut Pública. Journals of epidemiology and public health. URL: http://www.ub.es/isp/ links.htm

7 Departamento de Histología y Biología Celular. Universidad de Granada. Búsqueda de Revistas Científicas en Internet. URL: http://histolii.ugr.es/journals.html

8 National Library of Medicine. PubMed. URL: http:// www.ncbi.nlm.nih.gov/PubMed/

9 LaPorte RE, Marler E, Akazawa S, et al. The death of biomedical journals. BMF 1995;310:1387-90.

10 LaPorte RE. Internet server with targeted access would cure information deficiency in developing countries. BMF 1997; 314:980. 